\title{
Analisis Regresi Untuk Menentukan Pengaruh Karakteristik Pembudidaya terhadap Produksi Ikan Lele
}

\author{
YULIA PUSPITA SARI ${ }^{1}$, FITRA MULIA JAYA ${ }^{2}$ \\ 1,2Fakultas Perikanan, Universitas PGRI Palembang, Jl. Jend A. Yani Lorong Gotong Royong 9/10 Ulu \\ Kota Palembang 30116 \\ email: 1yuliaaman91@gmail.com,2f_muliajaya@yahoo.co.id
}

\begin{abstract}
ABSTRAK
Peningkatan jumlah konsumsi Ikan Lele di Kota Palembang menjadi peluang bagi pembudidaya untuk meningkatkan produksinya. Salah satu pendukung keberhasilan budidaya Ikan Lele yaitu dengan mengetahui faktor pendukungnya, baik eksternal maupun internal. Karakteristik pembudidaya tersebut adalah umur pembudidaya, pendidikan terakhir $\mathrm{p}$ embudidaya, jumlah anggota keluarga dan pengalaman sebagai pembudidaya. Analisis regresi adalah alat uji statistika yang dapat digunakan untuk melihat pengaruh karakteristik pembudidaya Ikan Lele terhadap rerata jumlah produksinya per tahun. Hasil analisis regresi menunjukkan secara simultan, karakteristik pembudidaya (umur, pengalaman, pendidikan dan jumlah tanggungan) berpengaruh terhadap rerata jumlah produksi per tahun. Nilai R2 yang diperoleh hanya $19,4 \%$, hal ini sejalan nilai $\mathrm{t}$ hitung yang diperoleh menunjukkan secara parsial, peubah bebas tidak berpengaruh terhadap rerata jumlah produksi per tahun.
\end{abstract}

Kata Kunci: Analisis Regresi, Karakteristik, Pembudidaya Ikan Lele, Kota Palembang

\begin{abstract}
Increasing the amount of consumption of catfish in the Palembang city is an opportunity for cultivators to increase production. One of the success supports of catfish cultivators is to know the supporting factors, both external and internal. The characteristics of the cultivator are the age, the last education, the number of family members and experience. Regression analysis is a statistical test that can be used to see the effect of characteristics of catfish cultivators on the average amount of production every year. The results of the regression analysis showed that simultaneously, the characteristics of cultivators (age, experience, education and number of family members) influenced the average amount of production every year. R2 value obtained was only $19.4 \%$, that was in line with the calculated $t$ value obtained partially, the independent variable has no effect on the average amount of production every year.
\end{abstract}

Keywords: Regression Analysis, Characteristics, Catfish Cultivators, Palembang City

\section{PENDAHULUAN}

Ikan yang berasal dari perairan darat merupakan salah satu sumber protein yang cukup digemari oleh masyarakat Kota Palembang, salah satunya adalah Ikan Lele. Ikan Lele memiliki kandungan protein yang cukup tinggi didalamnnya yaitu sekitar 17\% (Rustaman, 2015). Tingkat Konsumsi Ikan Lele mengalami peningkatan yang cukup besar, yakni sebesar 8,13\%. pada tahun 2013 sebanyak 2.458,0 ton/tahun meningkat menjadi $2.658,0$ ton/tahun pada tahun 2015. Ikan Lele menempati posisi ketiga setelah Ikan Patin dan Ikan Nila dalam hal jumlah konsumsi ikan air tawar terbanyak di Kota Palembang (DKP Sumsel, 2016). Peningkatan jumlah konsumsi ini tentunya merupakan peluang besar bagi pembudidaya Ikan Lele di Kota Palembang. Jumlah Rumah Tangga Perikanan (RTP) kolam dan keramba di Kota Palembang pada tahun 2014 sebanyak 905 meningkat menjadi 5.219 pada tahun 2016 (DKP Kota Palembang, 2016). 
Salah satu pendukung keberhasilan budidaya Ikan Lele yaitu dengan mengetahui faktor pendukungnya, baik eksternal maupun internal. Faktor pendukung internal dalam meningkatkan budidaya Ikan Lele diantaranya yaitu peningkatkan kreatifitas kerja dan kerja keras sumberdaya manusia dengan cara belajar pengalaman yang dimiliki dan kemampuan mengadopsi teknologi budidaya baru dan yang sedang berkembang dengan tujuan meningkatkan produksi Ikan Lele. (Riska dkk, 2015).

Menurut Pramono dkk. (2016) dalam usaha budidaya Ikan Lele ada beberapa hal yang harus di analisis, salah satunya adalah faktor karakteristik pembudidaya. Karakteristik pembudidaya tersebut adalah umur pembudidaya, pendidikan terakhir pembudidaya, jumlah anggota keluarga dan pengalaman sebagai pembudidaya.

Keberhasilan pembudidaya Ikan Lele sangat berpengaruh terhadap kemampuan pemenuhan permintaan pasar yang semakin meningkat, serta sangat berpengaruh terhadap perekonomian pembudidaya Ikan Lele. Analisis regresi adalah salah satu alat uji statistika yang digunakan untuk melihat hubungan pengaruh antar variabel, Sehingga penelitian menggunakan Analisis Regresi yang menyajikan bagaimana pengaruh karakteristik pembudidaya Ikan Lele terhadap jumlah produksinya sangat perlu untuk dilakukan sebagai bahan informasi bagi pembudidaya Ikan Lele di Kota Palembang.

\section{METODE}

Penelitian dilakukan di delapan kecamatan di Kota Palembang. Delapan kecamatan terpilih adalah Kecamatan Gandus, Kecamatan Ilir Barat 1, Kecamatan Kalidoni, Kecamatan Plaju, Kecamatan Seberang Ulu 1, Kecamatan Seberang Ulu 2, Kecamatan Sematang Borang dan Kecamatan Sukarami. Data dikumpulkan melalui wawancara kepada pembudidaya Ikan Lele. Analisis data menggunakan Analisis Regresi Linier dengan Software SPSS 21. Analisis regresi digunakan untuk melihat besar pengaruh variabel karakteristik pembudidaya terhadap jumlah produksinya. Variabel dependen dalam penelitian ini adalah rerata panen pembudidaya pertahun (kg). Sedangkan variabel independennya adalah umur $\left(X_{1}\right)$, pengalaman $\left(X_{2}\right)$, pendidikan terakhir $\left(X_{3}\right)$, dan Jumlah Anggota Keluarga yang menjadi tanggungan $\left(X_{4}\right)$.

Regresi Linier Berganda adalah analisis yang menggambarkan hubungan secara linear antara dua atau lebih peubah bebas $\left(X_{1}, X_{2}, \cdots X_{n}\right)$ dengan variabel terikat $(Y)$ yang dituliskan dalam persamaan matematik sebagai berikut:

$Y_{i}=\alpha+\beta_{1} X_{1}+\beta_{2} X_{2}+\beta_{3} X_{3}+\cdots+\beta_{n} X_{n}+e$

$\alpha$ dan $\beta$ adalah parameter koefisien regresi yang akan diduga nilainya. Sedangkan $e$ merupakan komponen error yang tidak diamati dan diasumsikan sebagai peubah acak (Juanda, 2009).

Analisis Regresi Linier mempunyai empat asumsi yang harus dipenuhi, yaitu $e_{i}$ menyebar saling bebas mengikuti sebaran normal; non multikolinieritas, yaitu tidak adanya hubungan antar peubah bebas $\left(E\left(X_{i}, X_{j}\right)=0\right.$, untuk semua $i \neq j ; \quad e_{i}$ memiliki ragam homogen (homoskedastisitas) atau sering disebut juga dengan tidak adanya masalah heteroskadisitas; dan $e_{i}$ tidak terikat terhadap peubah bebas (Mattjik \& Sumetajaya, 2008).

Tabel 1. Demografi Responden

\begin{tabular}{|l|r|r|r|r|r|}
\hline & $\begin{array}{c}\text { Umur } \\
\left(X_{1}\right)\end{array}$ & $\begin{array}{c}\text { Pengalaman } \\
\left(X_{1}\right)\end{array}$ & $\begin{array}{c}\text { Pendidikan } \\
\left(X_{1}\right)\end{array}$ & $\begin{array}{c}\text { Jumlah } \\
\text { Tanggungan } \\
\left(X_{1}\right)\end{array}$ & $\begin{array}{c}\text { Rerata } \\
\text { Produksi/tahun } \\
(Y)\end{array}$ \\
\hline Jumlah & 80 & 80 & 80 & 80 & 80 \\
Modus & 0 & 0 & 0 & 0 & 0 \\
Minimum & 40 & 2 & 3 & 0 & 3000 \\
Maximum & 19 & 1 & 1 & 0 & 500 \\
\hline
\end{tabular}




\section{HASIL DAN PEMBAHASAN}

\section{Demografi Pembudidaya Ikan Lele}

Setiap kecamatan terpilih diwakili oleh 10 orang pembudidaya sebagai responden. Sehingga terdapat total sebanyak 80 responden. Demografi responden disajikan pada Tabel 1. Berdasarkan Tabel 1, Umur responden paling banyak berusia 40 tahun, dengan rentang umur dari 19 tahun sampai 70 tahun dan pendidikan terakhir yang paling banyak adalah SMA, dengan rentang pendidikan mulai dari SD sampai SMA. Dari 80 responden, kebanyakan memiliki pengalaman 2 tahun, dengan pengalaman minimum 1 tahun dan paling lama yaitu telah berpengalaman selama 24 tahun sebagai pembudidaya Ikan Lele. Masih banyak pembudidaya yang masih berstatus belum menikah (belum memiliki tanggungan). Namun pembudidaya paling banyak memiliki 5 orang tanggungan.

\section{Analisis Regresi Linier}

Hasil ouput dengan menggunakan software SPSS 21 dirangkum dan disajikan pada Tabel 2.

Tabel 2. Ringkasan Output Software SPSS 21

\begin{tabular}{|c|c|c|c|c|c|}
\hline Model & R.Square & $\mathbf{F}$ & $\mathbf{t}$ & VIF & Durbin-Watson \\
\hline Umur & \multirow{4}{*}{0,194} & \multirow{4}{*}{4,512} & $-0,006$ & 1,438 & \multirow{4}{*}{1,722} \\
\hline Pengalaman & & & 2,869 & 1,331 & \\
\hline Pendidikan & & & 2,060 & 1,132 & \\
\hline Jumlah Tanggungan & & & 0,275 & 1,079 & \\
\hline
\end{tabular}

Hubungan secara linear antara peubah bebas $\left(X_{1}, X_{2}, X_{3}\right.$, dan $\left.X_{4}\right)$ dengan variabel terikat $(Y)$ yang dituliskan dalam persamaan berikut:

$Y_{i}=-968,5-0,231 X_{1}+174,805 X_{2}+678,053 X_{3}+505,359 X_{4}$

Berdasarkan model hubungan linier yang diperoleh diatas, dapat dijelaskan bahwa variabel umur $\left(X_{1}\right)$ berpengaruh negatif terhadap rerata jumlah produksi pembudidaya Ikan Lele, sedangkan variabel pengalaman $\left(X_{1}\right)$, variabel pendidikan $\left(X_{2}\right)$, variabel jumlah tanggungan $\left(X_{1}\right)$ berpengaruh positif terhadap rerata jumlah produksi pembudidaya Ikan Lele.

\section{Kebaikan Model}

Melihat kebaikan Model Regresi yang diperoleh dilakukan dengan melihat nilai dari $R^{2}$. Hasil output SPSS 21 diperoleh nilai $R^{2}$ hanya sebesar 19,4\%. Artinya kemampuan model dalam menerangkan variasi variabel terikat sangatlah kecil (kurang dari 50\%). Sedangkan 80,6\% sisanya dijelaskan oleh variabel lain yang tidak dimasukkan ke dalam model.

\section{Uji Simultan dan Parsial}

Uji simultan dilihat berdasarkan nilai $F$ hitung yang diperoleh, yaitu sebesar 4,512, jika dibandingkan dengan nilai $F$. Tabel sebesar 1,376, artinya secara bersama-sama keempat variabel bebas berpengaruh terhadap rerata jumlah produksi budidaya Ikan Lele di Kota Palembang. Sedangkan secara parsial berdasarkan nilai t hitung yang diperoleh dan dibandingkan dengan nilai t tabel yaitu sebesar 101,879, maka disimpulkan bahwa secara parsial semua variabel bebas yang digunakan tidak berpengaruh terhadap rerata jumlah produksi budidaya Ikan Lele di Kota Palembang.

\section{SIMPULAN}

Hasil analisis menggunakan Analisis Regresi menunjukkan bahwa karakteristik pembudidaya Ikan Lele berpengaruh secara simultan terhadap rerata jumlah produksinya, namun secara 


\section{Yulia Puspita Sari dkk.}

parsial tidak berpengaruh. Nilai $R 2$ juga dalam kategori rendah, yaitu hanya 19,4\%, jadi model yang dihasilkan belum begitu dapat menjelaskan variasi variabel terikat.

\section{DAFTAR PUSTAKA}

Dinas Kelautan dan Perikanan Provinsi Sumatera Selatan (DKP Sumatera Selatan). 2015. Statistik Perikanan Budidaya. Sumatera Selatan.

Dinas Kelautan dan Perikanan Kota Palembang. 2016. Statistik Perikanan Budidaya. Palembang

Juanda, B. 2009. Ekonometrika: Pemodelan dan Pendugaan. IPB Press. Bogor.

Mattjik, AA., Sumertajaya, IM. 2008. Perancangan Percobaan dengan Aplikasi SAS dan Minitab. IPB Press. Bogor.

Pramono, MD., Rahayu, ES., Ferichani, M. 2016. Analisis Faktor Faktor yang Mempengaruhi Produksi Pembenihan Ikan Lele Dumbo (Clarias gariepenus) di Kabupaten Wonogiri https://media.neliti.com/media/publications/176149-ID-analisis-faktor-faktor-yangmempengaruhi.pdf. Diakses tanggal 10 Juli 2018.

Riska, FF., Primyastanto, M., Abidin, Z. 2015. Strategi Pengembangan Usaha Budidaya Ikan Lele (Clarias sp.) Pada Usaha Perseorangan "Toni Makmur" Di Kawasan Agropolitan Desa Kauman Kecamatan Ngoro Kabupaten Jombang Jawa Timur. Jurnal ECSOFiM. 3 (1): 48-54.

Rustaman. 2015. Lele Ikan Favorit. Putra Amanah Murni. Jakarta. 